Article

\title{
Organic Cropping System Affects Grain Chemical Composition, Rheological and Agronomic Performance of Durum Wheat
}

\author{
Gaetano Pandino ${ }^{D}$, Emanuela Mattiolo, Sara Lombardo *, Grazia Maria Lombardo and \\ Giovanni Mauromicale $\mathbb{D}$
}

Dipartimento di Agricoltura, Alimentazione e Ambiente (Di3A), University of Catania, via Valdisavoia 5, 95123 Catania, Italy; g.pandino@unict.it (G.P.); emanuelamattiolo@alice.it (E.M.);

gm.lombardo@unict.it (G.M.L.); g.mauromicale@unict.it (G.M.)

* Correspondence: saralomb@unict.it; Tel.: +39-095-4783421

Received: 22 January 2020; Accepted: 12 February 2020; Published: 20 February 2020

\begin{abstract}
Durum wheat plays a central role for Italy, a country characterized by an historical tradition of pasta making. This crop is one of the major sources of starch in the Mediterranean diet, also providing substantial amounts of nutrients, either essential or healthy, such as minerals and phytochemicals. In this study, the effect of cropping system (organic (ORG) and conventional $(\mathrm{CONV})$ ) on the content of proteins, wet gluten, minerals, and total polyphenols (TPC), as well as on the antioxidant activity (AA) and yield characteristics were evaluated in nine genotypes of whole durum wheat. The analysis of variance confirmed the key role of cropping system, which explained more than $50 \%$ of the total variation for some minerals ( $\mathrm{Na}, \mathrm{K}$, and $\mathrm{Fe}$ ), and more than $80 \%$ for proteins, wet gluten, and TPC. The CONV reported the highest levels of proteins, wet gluten, and ash, whereas the TPC and AA were statistically higher in the ORG ones. The quality traits under study were also genotype dependent. For instance, 'Ramirez' had a higher ash content under ORG than CONV, while 'Core' had an opposite behavior. This study provides a better understanding about the effect of both cropping system (ORG vs. CONV) and genotype on the yield and qualitative traits of the whole grain durum wheat.
\end{abstract}

Keywords: cropping system; antioxidant activity; wet gluten; polyphenols; minerals

\section{Introduction}

Wheat is ranked fourth in the top 50 commodities of FAO list (http://faostat3.fao.org/browse/ rankings/commodities_by_regions/E). Durum wheat (Triticum turgidum L. ssp. durum) represents about $8 \%$ of the total world wheat production [1]. It is one of the most widely grown food crops in the Mediterranean area: it can be used as it is (as in the case of cuccia), or processed as semolina for the production of pasta, couscous, bulgur, and bread [2]. In the last 10 years in Italy, where there is an historical tradition of pasta making and the crop has a central role in the human diet and economy [3], 38,585 tonnes of wheat were produced [4].

Wheat not only is a major source of starch and energy in the diet, but also provides substantial amount of several compounds which are essential or beneficial for health, notably proteins, vitamins (mainly B ones), dietary fiber, minerals and phytochemicals, that are concentrated in the bran and germ components of whole grains [5,6]. In particular, whole grain products are recommended for healthy diets being recognized sources of dietary fiber and antioxidant compounds [7]. The former, especially phenolic compounds, are located in the outer layer of cereal seeds, both in free and insoluble forms. Actually, the health properties of whole grain appear to be dependent on a synergism among its 
nutraceutical compounds, rather than on the effect of a specific compound. Many researchers [5,6,8,9] reported that refined-grain products are relatively nutritionally poor in some constituents such as fiber, vitamins E and B-6, antioxidants, and phytoestrogens, because the endosperm is separated from the bran and germ before milling. These constituents may protect against cardiovascular disease, stroke, type 2 diabetes, obesity, and certain cancer diseases. Dietary fiber has been shown to decrease glucose, insulin, and serum lipid concentration in both diabetic and non-diabetic persons [10]. For these reasons, the Food and Drug Administration approved a health claim for the whole grain foods that contain $\geq 51 \%$ whole grain ingredients by weight per reference amount customarily consumed [11].

Whole grain is also rich in minerals, which are essential elements that activate enzymes performing metabolic functions in human body. Their concentration depends on genotype, environmental and growing conditions [12]. Moreover, Zhang et al. [13] observed a strong positive correlation between the levels of some minerals and proteins. These are mainly located in germ $(34.0 \%)$ and aleurone $(22.8 \%)$, while a lower percentage of protein is distributed in testa $(5.7 \%)$ and pericarp (5.1\%). In particular, gluten complex specific proteins are important for the processing of wheat to produce bread, other baked goods, noodles and pasta, besides a range of functional ingredients [14]. A cause-and-effect relationship has been established between gluten fraction, rheological and baking properties of wheat flour [15].

Nowadays, the demand of organic foodstuff is increasing as a consequence of the general opinion of the good impact effect on health and on the environment, since synthetic fertilizers and pesticides are not allowed [16]. Agricultural cropping systems (organic (ORG) and conventional $(\mathrm{CONV})$ ) may differ greatly in terms of amount and sources of fertilizers, crop protection strategies, and rotation. Dangour et al. [17] concluded a systemic review reporting that the difference existing between organically and conventionally produced foodstuffs was unlikely to be of public health relevance, since there was no evidence to support the selection of organically produced foodstuffs over conventionally ones to increase the intake of specific nutrients or nutritionally relevant substances. Regarding wheat, the literature sometimes appeared to be contradictory in relation to the effect of cropping system on crop yield and quality. For instance, Mäder et al. [16] observed no significant differences in the concentration of most minerals between ORG and CONV cropping systems, whereas others found significant differences $[18,19]$. Therefore, considering the poor availability of data on the response of durum whole grain to ORG and CONV cropping systems, the present work was aimed at investigating the effect of cropping systems on the level of some nutrients (proteins, ash, and minerals), phytochemical compounds (as total polyphenols content), and antioxidant activity, as well as on the yield and the rheological aptitude, in nine genotypes of durum wheat.

\section{Materials and Methods}

\subsection{Plant Material and Field Trials}

The field experiment was conducted at the experimental station of Catania University, located in western Sicily $\left(37^{\circ} 30^{\prime} 51^{\prime \prime} \mathrm{N}, 15^{\circ} 03^{\prime} \mathrm{E}, 10 \mathrm{~m}\right.$ a.s.l.), on typic and vertic xerochrepts soil (USDA, soil Taxonomy, 1999 ) with a clay texture ( $45 \%$ clay, $37 \%$ silt, and $18 \%$ sand). Soil chemical characteristics were $0.8 \mathrm{~g} \mathrm{~kg}^{-1}$ of total nitrogen $(\mathrm{N}), 10 \mathrm{mg} \mathrm{kg}^{-1}$ of phosphorous assimilable $\left(\mathrm{P}_{2} \mathrm{O}_{5}\right)$, and $347 \mathrm{mg} \mathrm{kg}^{-1}$ of potassium exchangeable $\left(\mathrm{K}_{2} \mathrm{O}\right)$.

The local climate is semiarid-Mediterranean with mild winter and hot, rainless summer. We used two adjoining fields, one for each cropping system under study, in the same area to guarantee the same pedoclimatic conditions for both types of cropping systems. These experimental fields were separated by rows of trees, resulting in a total distance of $50 \mathrm{~m}$. In addition, they had the same crop rotation, involving durum wheat and filed bean. In each cropping system (CONV and ORG), a randomized block design with four replications was adopted. Each block included the nine genotypes reported in Table 1. 
Table 1. Main agronomic characteristics of the nine durum wheat genotypes under study.

\begin{tabular}{cccccc}
\hline Genotype & $\begin{array}{c}\text { Biological } \\
\text { Cycle }\end{array}$ & $\begin{array}{c}\text { Adaptability } \\
(\mathbf{\%})^{+}\end{array}$ & $\begin{array}{c}\text { Plant Height } \\
(\mathbf{c m})\end{array}$ & $\begin{array}{c}\text { 1000 Seeds } \\
\text { Weight }(\mathbf{g})\end{array}$ & Reference \\
\hline Anco Marzio & Medium-early & 70 & 87 & 42 & {$[20]$} \\
Claudio & Medium & 78 & 87 & 45 & {$[20]$} \\
Core & Medium-early & 75 & 80 & 55 & Lombardo $\ddagger$ \\
Duilio & Early & 75 & 83 & 46 & {$[20]$} \\
Mongibello & Medium-early & 70 & 75 & 48 & Lombardo \\
Ramirez & Medium & 89 & 86 & 41 & {$[20]$} \\
Saragolla & Early & 76 & 80 & 42 & {$[20]$} \\
Simeto & Medium-early & 70 & 79 & 50 & [20]/Lombardo \\
Tirex & Medium-early & 59 & 81 & 45 & [20] \\
\hline
\end{tabular}

${ }^{\dagger}$ Expressed as percentage of cultivated fields with grain yield higher than the Sicilian average; ${ }^{\ddagger}$ Personal estimated data.

In both cropping systems, seeds were sown at a density of 350 viable seeds $\mathrm{m}^{-2}$ in December 2015. The size of single plot was $4 \times 6 \mathrm{~m}$ and consisted of 20 rows, each $6 \mathrm{~m}$ long and spared $0.20 \mathrm{~m}$. Tillage consisted of a $40 \mathrm{~cm}$ depth ploughing by harrowing in October. The CONV cropping system was managed in accordance with the local farming practices, while the crop management under ORG cropping system followed current EU regulations (889/2008). The same fertilizer doses were applied under CONV and ORG cropping systems, namely a pre-sowing application of $50 \mathrm{~kg} \mathrm{ha}^{-1} \mathrm{~N}$ and $100 \mathrm{~kg} \mathrm{ha}^{-1}$ of $\mathrm{P}_{2} \mathrm{O}_{5}$ in the form of synthetic fertilizer (CONV) or a mixture of feathers and torrefied bone and meat meal (ORG). A further $30 \mathrm{~kg} \mathrm{ha}^{-1} \mathrm{~N}$ was supplied at the full tillering (stage 25) [21] as urea $(\mathrm{CONV})$ or a mixture of dried manure and hydrolyzed pelt (ORG). In the CONV cropping system the weeding was performed with MPPA at the first detectable node (stage 31) [21], while in ORG the crop was kept free of weeds through hand hoeing when necessary. Harvest was done at full ripeness (stage 92) [21] during the last 10 days of June under both CONV and ORG cropping systems. The grain yield was determined on $11.2 \mathrm{~m}^{2}$ per plot (four central meters of 14 middle rows) to avoid border effects and was expressed at $13 \%$ moisture level.

\subsection{Meteorological Trend}

The total annual rainfall amounted to $397 \mathrm{~mm}$, with October and May recorded as the driest months (16 and $12 \mathrm{~mm}$, respectively), and December as the wettest $(82 \mathrm{~mm})$. The winter was mild, since the minimum temperature never dropped below $5{ }^{\circ} \mathrm{C}$ and temperature excursion was $10{ }^{\circ} \mathrm{C}$, on average. In March the total rainfall decreased, and mean temperatures increased improving the grain filling.

\subsection{Reagents and Solvents}

Analytical grade reagents were purchased from Sigma Aldrich (Milan, Italy). K, Na, Ca, Mg, P, $\mathrm{Fe}, \mathrm{Cu}, \mathrm{Mn}$, and $\mathrm{Zn}$ standards were obtained from Perkin Elmer (Norwalk, CT, USA). Milli-Q system (Millipore Corp., Bedford, MA, USA) ultrapure water was used throughout this research.

\subsection{Grain Quality Evaluation}

The wet gluten and deformation energy of dough $(\mathrm{W})$ were determined, according to Approved Methods 38-12.02 and 54-30.02 of American Association of Cereal Chemists (AACC International, 2000) and expressed as J and \%, respectively. Nitrogen content was determined following Kjeldahl method using potassium sulfate and selenium as catalyst and sulphuric acid $0.1 \mathrm{~N}$ for titration. Factor 5.7 was applied to obtain the content of protein (expressed as \% of dry matter, DM). 


\subsection{Total Polyphenols Content and Antioxidant Activity}

Total polyphenols content (TPC) was quantified using a modified Folin-Ciocalteu method [22]. About $1 \mathrm{~g}$ of dry material was diluted in $4 \mathrm{~mL}$ methanol $80 \%$ and stirred at room temperature for $1 \mathrm{~h}$, with shaking. The mixture was centrifuged at $5000 \times \mathrm{g}$ for $5 \mathrm{~min}$ at $25^{\circ} \mathrm{C}$; then, a suitably diluted aliquot was purified with a C-18 end-capped cartridge Phenomenex-Strata (Castel Maggiore, Bologna, Italy) in order to avoid interference by other reducing substances in the assay, and then mixed with Folin-Ciocalteu reagent at room temperature for $2 \mathrm{~min}$. Sodium carbonate $(5 \%, w / v)$ was added and the mixture was allowed to rest at $40{ }^{\circ} \mathrm{C}$ for $20 \mathrm{~min}$ in a thermostatic bath. The absorbance was read at $725 \mathrm{~nm}$ by a spectrophotometer Shimadzu 1601 UV-Visible (Shimadzu Corp., Tokyo, Japan). The content was determined on the basis of a standard calibration curve generated with increasing concentrations of ferulic acid and expressed as $g$ of ferulic acid equivalent $\mathrm{kg}^{-1}$ of DM.

The antioxidant activity (AA) of the extracts was evaluated as percentage inhibition of DPPH radical. An aliquot $(0.1 \mathrm{~mL})$ of each extract used for TPC assay, was added to $3.9 \mathrm{~mL}$ of freshly prepared methanolic solution containing $0.24 \mathrm{~g} \mathrm{~L}^{-1} \mathrm{DPPH}$, and held in the dark for $30 \mathrm{~min}$ at room temperature. Then, the absorbance was measured at $515 \mathrm{~nm}$ in the spectrophotometer. The percentage inhibition of DPPH was calculated according to Brand-Williams et al. [23].

\subsection{Ash and Mineral Analysis}

The ash content was determined by Approved Methods 08-12.01 of American Association of Cereal Chemists (AACC International, 2000) and expressed as \% of DM. Mineral content was carried out using a Perkin Elmer AAnalyst 200 flame atomic absorption spectrometer (Norwalk, CT, USA) equipped with a multi-element hollow cathode lamp and a deuterium background correction system. The quantification of each mineral in the sample was performed by calibration curves generated by using the specific standard. All data presented are mean values of two independent experiments and expressed as $\mathrm{mg} \mathrm{kg}^{-1}$ of fresh weight (FW).

\subsection{Statistical Analysis}

Data on wet gluten, $\mathrm{W}$ index, ash, AA, minerals, and TPC were subjected to a two-way ('genotype $\times$ cropping system') analysis of variance (ANOVA). When the $F$-test from ANOVA was significant, an LSD test was applied to compare the means. The CoHort software package ver. 6.4 (CoHort software, Monterey, CA, USA) was used.

\section{Results and Discussion}

\subsection{Yield and Rheological Traits}

The reduction of available nitrogen in the soil is notoriously the most critical point of ORG wheat, because of its effects on both the yield and protein content. Here, the cropping system explained more than $80 \%$ of total variation for yield, protein content, and wet gluten (Table 2). As expected, the CONV yields were higher than ORG ones (3.3 vs. $2.1 \mathrm{t} \mathrm{ha}^{-1}$; Table 3), as previously observed by Quaranta et al. [24].

Table 2. Mean square per each source of variation (percentage of total) resulting from the ANOVA.

\begin{tabular}{cccccccc}
\hline Source of Variation & $\begin{array}{c}\text { Degree of } \\
\text { Freedom }\end{array}$ & Yield & Protein & $\begin{array}{c}\text { Wet } \\
\text { Gluten }\end{array}$ & W $^{+}$ & TPC $\ddagger$ & AA $^{\S}$ \\
\hline Cropping system (CS) & 1 & $8.6^{* * *}$ & $96.2^{* * *}$ & $89.4^{* * *}$ & $43.4^{* * *}$ & $87.5^{* * *}$ & $43.1^{* * *}$ \\
Genotype (G) & 8 & $79.1^{* * *}$ & $1.3^{* * *}$ & $2.3^{\mathrm{NS}}$ & $45.7^{* * *}$ & $11.0^{* * *}$ & $54.2^{* * *}$ \\
CS $\times \mathrm{G}$ & 8 & $10.5^{* * *}$ & $2.5^{* * *}$ & $5.6^{\mathrm{NS}}$ & $10.1^{* * *}$ & $1.5^{\mathrm{NS}}$ & $2.7^{\mathrm{NS} \mathbb{I}}$ \\
\hline
\end{tabular}

${ }^{\dagger} \mathrm{W}$ : deformation energy of dough; ${ }^{\ddagger} \mathrm{TPC}$ : total polyphenols content; $§$ AA: antioxidant activity, ${ }^{* * *}$ indicate significant at $p \leq 0.001$; ${ }^{\text {II }}$ NS: not significant. 
Table 3. Yield ( $\mathrm{t} \mathrm{ha}^{-1}$ at $13 \%$ moisture) and quality parameters as affected by 'cropping system $(\mathrm{CS}) \times$ genotype $(\mathrm{G})$ ' interaction. Different letters (a-e or A, B) within each main factor indicate significant differences (LSD test, $p \leq 0.05$ ). All data are expressed as mean \pm standard deviation.

\begin{tabular}{|c|c|c|c|c|c|c|c|c|c|c|c|c|c|c|c|}
\hline \multirow{2}{*}{ Variable } & \multicolumn{4}{|c|}{ Yield } & \multicolumn{4}{|c|}{ Protein (\% DM) } & \multicolumn{4}{|c|}{$\mathrm{W}^{+}\left(\times 10^{-4} \mathrm{~J}\right)$} & \multicolumn{3}{|c|}{ Wet Gluten (\%) } \\
\hline & ORG $\ddagger$ & CONV $\S$ & \multicolumn{2}{|c|}{ Mean } & ORG & CONV & \multicolumn{2}{|c|}{ Mean } & ORG & CONV & \multicolumn{2}{|c|}{ Mean } & ORG & CONV & Mean \\
\hline Anco Marzio & $1.9 \pm 0.20$ & $2.8 \pm 0.11$ & 2.4 & bc & $10.8+0.06$ & $126+006$ & 117 & b & $704+896$ & $1206+321$ & 955 & $c$ & $262+120$ & $268+018$ & \\
\hline Claudio & $2.2 \pm 0.31$ & $3.1 \pm 0.40$ & 2.7 & bc & $10.9 \pm 0.39$ & $11.3 \pm 0.06$ & 11.1 & c & $75.0 \pm 8.94$ & $95.0 \pm 2.35$ & 85.0 & $\mathrm{~cd}$ & $23.7 \pm 0.57$ & $291+276$ & 26.4 \\
\hline Core & $2.1 \pm 0.15$ & $5.3 \pm 0.41$ & 3.7 & $\mathbf{a}$ & $10.5 \pm 0.06$ & $13.4 \pm 0.28$ & 11.9 & $a b$ & $76.0 \pm 8.94$ & $100.4 \pm 12.58$ & 88.2 & cd & $26.6 \pm 2.26$ & $33.1 \pm 2.72$ & 29.9 \\
\hline Duilio & $1.4 \pm 0.21$ & $2.9 \pm 0.30$ & 2.2 & bc & $10.9 \pm 0.34$ & 12.9 & 11.9 & $a b$ & $108.4 \pm 6.11$ & $128.0 \pm 13.98$ & 118.2 & $\mathbf{b}$ & $28.8 \pm 3.04$ & $31.3 \pm 0.67$ & 30.1 \\
\hline Mongibello & $3.7 \pm 0.45$ & $2.7 \pm 0.15$ & 3.2 & $a b$ & $11.7 \pm 0.23$ & $12.6 \pm 0.06$ & 12.1 & $\mathbf{a}$ & $209.8 \pm 17.39$ & $157.4 \pm 11.37$ & 183.6 & $\mathbf{a}$ & $28.5 \pm 0.49$ & $30.3 \pm 1.59$ & 29.4 \\
\hline Ramirez & $1.4 \pm 0.26$ & $4.0 \pm 0.29$ & 2.7 & bc & $10.3 \pm 0.06$ & 12.0 & 11.1 & c & $52.0 \pm 5.61$ & $98.0 \pm 15.56$ & 75.0 & de & $25.1 \pm 1.34$ & $29.0 \pm 0.99$ & 27.1 \\
\hline Saragolla & $2.3 \pm 0.14$ & $3.0 \pm 0.31$ & 2.6 & bc & $10.8 \pm 0.11$ & $12.6 \pm 0.06$ & 11.7 & $\mathbf{b}$ & $65.2 \pm 13.72$ & $128.0 \pm 11.66$ & 96.6 & c & $23.0 \pm 1.10$ & $32.6 \pm 3.80$ & 27.8 \\
\hline Simeto & $1.7 \pm 0.30$ & $2.1 \pm 0.31$ & 1.9 & c & $10.1 \pm 0.17$ & $13.2 \pm 0.11$ & 11.6 & $\mathbf{b}$ & $71.6 \pm 20.19$ & $95.8 \pm 8.04$ & 83.7 & $\mathrm{~cd}$ & $22.0 \pm 0.92$ & $36.6 \pm 0.32$ & 29.3 \\
\hline Tirex & $2.3 \pm 0.18$ & $3.6 \pm 0.27$ & 3.0 & ac & $101 \pm 0.11$ & $13.1 \pm 0.11$ & 11.6 & $\mathbf{b}$ & $58.6 \pm 8.73$ & $69.4 \pm 3.78$ & 64.0 & $\mathbf{e}$ & $24.2 \pm 1.34$ & $32.7 \pm 1.38$ & 28.4 \\
\hline Mean & 2.1 & 3.3 & & & 10.7 & 12.6 & & & 87.4 & 110.3 & & & 25.3 & 31.3 & \\
\hline
\end{tabular}

LSD

1.0

0.3

18.1

NS II

${ }^{\dagger}$ W: deformation energy of dough; ${ }^{\ddagger}$ ORG: organic cropping system; ${ }^{\S}$ CONV: conventional cropping system; ${ }^{\text {Il }}$ NS: not significant. 
Only 'Mongibello' showed the higher yield under the ORG cropping system ( $3.7 \mathrm{t} \mathrm{ha}^{-1}$ at moisture $13 \%)$, since it is probably better adapted to low available soil nitrogen conditions. This genotype also achieved in the ORG cropping system a higher protein content than the others (Table 3), confirming its better ability in nitrogen uptake under stress nutritional conditions. Quaranta et al. [24] made a similar conclusion on three genotypes of durum wheat. 'Claudio' and 'Ramirez' were characterized by lowest protein content $(11.1 \% \mathrm{DM})$. Overall, the protein content here reported was lower than the values of previous works $[3,24]$. This discrepancy could be attributable to the different genotypes adopted and pedo-climatic conditions of experimental locations. According to Vaccari et al. [25], an increase of temperatures induced a lower protein concentration in the grains, as observed in our samples. Changes in protein content at various stages of grain development of durum wheat genotypes have been already reported by Galterio et al. [26]. The total protein and wet gluten content play critical roles in determining flour's processing suitability. The wet gluten represents physic-chemical properties of gluten, such as also the gluten index. Here, the wet gluten did not show statistically significant differences among the genotypes, as well the interaction 'cropping system $\times$ genotype'. This result could indicate that for the genotypes under study there was no correlation between the total protein content and the wet gluten, in accordance with Kovacs et al. [27]. In addition, the content of pentosanes and hemicelluloses appeared to have a strong effect on the wet gluten [28]. In contrast, Simic et al. [29] considered the genotype as the most important factor influencing the qualitative characteristics of gluten. Nevertheless, these authors did not investigate the effect of cropping system, as done in our study. Along with the wet gluten, the $\mathrm{W}$ is an important rheological property for defining the end-use quality of the flour. ANOVA results displayed that both cropping system and genotype had a similar influence on this parameter (Table 2). The CONV cropping system reported the higher value than the ORG ones (110.3 vs. $\left.87.4 \times 10^{-4} \mathrm{~J}\right)$ for all the studied genotypes excepted for 'Mongibello' (Table 3). This registered the highest level of $\mathrm{W}$ in both cropping systems compared to the other genotypes. It is interesting to note that the genotypes with the lowest values of $\mathrm{W}$ also reported the highest level for ash ('Ramirez' and 'Tirex') (Tables 3 and 4). In a previous work, the ash content in wheat was negatively correlated to $\mathrm{W}[30]$. 
Table 4. Ash (\% dry matter) and macro-minerals content ( $\mathrm{mg} \mathrm{kg}^{-1}$ fresh weight) as affected by 'cropping system (CS) $\times$ genotype (G)' interaction. Different letters (a-d or A, B) within each main factor indicate significance differences (LSD test, $p \leq 0.05$ ). All data are expressed as mean \pm standard deviation.

\begin{tabular}{|c|c|c|c|c|c|c|c|c|c|c|c|c|c|c|}
\hline \multirow{2}{*}{ Variable } & \multicolumn{4}{|c|}{ Ash } & \multicolumn{4}{|c|}{$\mathbf{K}$} & \multicolumn{3}{|c|}{$\mathrm{Na}$} & \multicolumn{3}{|c|}{$\mathrm{Na} / \mathrm{K}$} \\
\hline & $\mathrm{ORG}^{+}$ & CONV $\ddagger$ & \multicolumn{2}{|c|}{ Mean } & ORG & CONV & \multicolumn{2}{|c|}{ Mean } & ORG & CONV & Mean & ORG & CONV & Mean \\
\hline & & & & & & & & & & & & & & \\
\hline Anco Marzio & $1.6 \pm 0.12$ & $1.5 \pm 0.09$ & 1.6 & c & $4944 \pm 60.2$ & $3205 \pm 17.6$ & 4074 & c & $75 \pm 0.9$ & $75 \pm 2.3$ & 75 & 0.02 & 0.02 & 0.02 \\
\hline Claudio & $1.7 \pm 0.05$ & $1.7 \pm 0.01$ & 1.7 & bc & $3594 \pm 205.3$ & $5268 \pm 380.8$ & 4431 & bc & $73 \pm 1.4$ & $72 \pm 2.1$ & 72 & 0.02 & 0.01 & 0.01 \\
\hline Core & $1.6 \pm 0.07$ & $2.2 \pm 0.05$ & 1.9 & $a b$ & $4963 \pm 283.7$ & $4508 \pm 306.4$ & 4736 & $\mathbf{b}$ & $77 \pm 0.9$ & $69 \pm 1.3$ & 73 & 0.02 & 0.02 & 0.02 \\
\hline Duilio & $1.7 \pm 0.02$ & $1.7 \pm 0.05$ & 1.7 & bc & $5240 \pm 268.7$ & $5161 \pm 139.5$ & 5200 & $\mathbf{a}$ & $76 \pm 0.5$ & $76 \pm 1.7$ & 76 & 0.01 & 0.01 & 0.01 \\
\hline Mongibello & $1.9 \pm 0.02$ & $2.0 \pm 0.19$ & 1.9 & $\mathbf{a b}$ & $5236 \pm 267.0$ & $3296 \pm 213.0$ & 4266 & c & $79 \pm 2.2$ & $74 \pm 1.4$ & 76 & 0.02 & 0.02 & 0.02 \\
\hline Ramirez & $2.4 \pm 0.12$ & $2.1 \pm 0.15$ & 2.2 & a & $3241 \pm 90.9$ & $3054 \pm 29.6$ & 3148 & d & $77 \pm 1.3$ & $74 \pm 2.7$ & 76 & 0.02 & 0.02 & 0.02 \\
\hline Saragolla & $2.0 \pm 0.05$ & 2.0 & 2.0 & $a b$ & $3153 \pm 25.0$ & $3151 \pm 209.4$ & 3152 & d & $77 \pm 0.8$ & $68 \pm 2.9$ & 72 & 0.02 & 0.02 & 0.02 \\
\hline Simeto & $1.7 \pm 0.04$ & $2.1 \pm 0.13$ & 1.9 & $a b$ & $5109 \pm 106.8$ & $3103 \pm 301.3$ & 4106 & c & $75 \pm 2.9$ & $77 \pm 2.3$ & 76 & 0.01 & 0.02 & 0.02 \\
\hline Tirex & $1.7 \pm 0.01$ & $2.6 \pm 0.15$ & 2.2 & $\mathbf{a}$ & $5140 \pm 19.2$ & $3068 \pm 434.8$ & 4104 & c & $73 \pm 2.0$ & $66 \pm 0.5$ & 69 & 0.01 & 0.02 & 0.02 \\
\hline Mean & 1.8 & 2.0 & & & 4513 & 3757 & & & 76 & 72 & & 0.02 & 0.02 & \\
\hline
\end{tabular}

LSD

interaction

$\mathrm{CS} \times \mathrm{G}$

0.3

NS $\S$

NS

NS

ORG: organic cropping system; ${ }^{\ddagger}$ CONV: conventional cropping system; ${ }^{\S}$ NS: not significant. 


\subsection{Total Polyphenols Content and Antioxidant Activity}

The TPC and AA of the investigated whole grain genotypes are presented in Table 5. Here, ANOVA revealed that the cropping system explained more than $80 \%$ of the total variation (Table 3 ). In particular, the ORG cropping system recorded a higher TCP than CONV ones (2.6 vs. $1.9 \mathrm{~g} \mathrm{~kg}^{-1}$ of DM). Additionally, Zuchowsky et al. [31] concluded that ORG wheat contained more polyphenols than CONV ones. Similar results were observed in other crops, such as tomato and potato [32,33]. The results also showed some significant differences in AA, although mean values did not vary much among the genotypes studied (Table 5). The highest value was found for 'Duilio' ( $85 \%$ inhibition of DPPH), while the lowest for 'Claudio' (69\% inhibition of DPPH). As reported for the TPC, also for the AA the ORG cropping system had the highest value (77\% inhibition of DPPH). We also observed a strong correlation between AA and TPC $\left(\mathrm{R}^{2}=0.97, p \leq 0.01\right)$, which was consistent with results reported by previous works carried out on wheat grain $[8,34]$. However, our results contrast with those reported by Yu et al. [35], who found no correlation between total polyphenols content and radical scavenging capacity.

Table 5. Total polyphenols content (TPC; $\mathrm{g} \mathrm{kg}^{-1}$ dry matter) and antioxidant activity (AA; \% inhibition of DPPH) as affected by 'cropping system (CS) $\times$ genotype $(\mathrm{G})$ ' interaction. Different letters (a-e or A, B) within each main factor indicate significance differences (LSD test, $p \leq 0.05$ ). All data are expressed as mean \pm standard deviation.

\begin{tabular}{|c|c|c|c|c|c|c|c|c|c|c|c|}
\hline \multirow{3}{*}{$\begin{array}{l}\text { Variable } \\
\text { Genotype }\end{array}$} & \multicolumn{5}{|c|}{ TPC } & \multicolumn{6}{|c|}{ AA } \\
\hline & $\mathrm{ORG}^{\dagger}$ & \multicolumn{2}{|c|}{ CONV $\ddagger$} & \multicolumn{2}{|c|}{ Mean } & \multicolumn{2}{|c|}{ ORG } & \multicolumn{2}{|c|}{ CONV } & \multicolumn{2}{|c|}{ Mean } \\
\hline & \multirow[b]{2}{*}{$2.7 \pm 0.06$} & & & \multirow[b]{2}{*}{2.2} & \multirow[b]{2}{*}{ bc } & \multirow{2}{*}{\multicolumn{2}{|c|}{$75 \pm 3.5$}} & \multirow{2}{*}{\multicolumn{2}{|c|}{$74 \pm 2.9$}} & \multirow[b]{2}{*}{74} & \multirow[b]{2}{*}{$\mathrm{cd}$} \\
\hline Anco Marzio & & \multicolumn{2}{|c|}{$1.7 \pm 0.20$} & & & & & & & & \\
\hline Claudio & $1.9 \pm 0.24$ & \multicolumn{2}{|c|}{$1.6 \pm 0.13$} & 1.7 & c & \multicolumn{2}{|c|}{$70 \pm 1.0$} & \multicolumn{2}{|c|}{$67 \pm 2.3$} & 69 & e \\
\hline Core & $2.2 \pm 0.19$ & \multicolumn{2}{|c|}{$1.7 \pm 0.22$} & 2.0 & bc & \multicolumn{2}{|c|}{$73 \pm 3.3$} & \multicolumn{2}{|c|}{$71 \pm 3.3$} & 72 & ce \\
\hline Duilio & $3.4 \pm 0.46$ & \multicolumn{2}{|c|}{$2.5 \pm 0.38$} & 2.9 & $\mathbf{a}$ & \multicolumn{2}{|c|}{$87 \pm 1.4$} & \multicolumn{2}{|c|}{$83 \pm 1.8$} & 85 & $\mathbf{a}$ \\
\hline Mongibello & $2.6 \pm 0.34$ & \multicolumn{2}{|c|}{$1.8 \pm 0.03$} & 2.2 & bc & \multicolumn{2}{|c|}{$74 \pm 3.2$} & \multicolumn{2}{|c|}{$74 \pm 0.8$} & 74 & cd \\
\hline Ramirez & $2.5 \pm 0.16$ & \multicolumn{2}{|c|}{$2.2 \pm 0.26$} & 2.3 & $\mathbf{b}$ & \multicolumn{2}{|c|}{$82 \pm 1.0$} & & 0.7 & 81 & $\mathbf{b}$ \\
\hline Saragolla & $2.7 \pm 0.38$ & & & 2.3 & $\mathbf{b}$ & $83=$ & & & 1.0 & 80 & $\mathbf{b}$ \\
\hline Simeto & $2.1 \pm 0.22$ & & & 1.8 & c & $74=$ & & & 1.0 & 70 & de \\
\hline Tirex & $3.0 \pm 0.05$ & & & 2.5 & $\mathbf{b}$ & $77=$ & & & 3.2 & 75 & c \\
\hline Mean & 2.6 & 1.9 & B & & & 77 & A & 74 & B & & \\
\hline LSD interaction & & & & & & & & & & & \\
\hline $\mathrm{CS} \times \mathrm{G}$ & & & & & & & & & $S$ & & \\
\hline
\end{tabular}

Regarding TPC, statistically significant differences were observed among genotypes. 'Duilio', followed by 'Ramirez' and 'Saragolla', had the highest amounts (2.9 and $2.3 \mathrm{~g} \mathrm{~kg}^{-1}$ of DM, respectively), while 'Claudio' and 'Simeto' showed the lowest content (1.7 and $1.8 \mathrm{~g} \mathrm{~kg}^{-1}$ of DM, respectively) (Table 5). Our results were in contrast with those reported by previous studies, which found that 'Anco Marzio' showed the highest content [3,22]. On the contrary, Martini et al. [36] observed that such genotype had the lowest content of TPC (as sum of free, conjugated, and bound phenolic acids). These discrepancies could be mainly attributable to the different environmental conditions, that have an important impact on the biosynthesis and accumulation of phenolic compounds. This hypothesis was supported by the consideration that previous findings reported that both cultivation area and season had a relevant role on the fluctuation of TPC $[37,38]$. Moreover, to our knowledge, previous investigations have not investigated the variation of TPC in relation to the cropping system. This might provide an additional explanation for such differences.

\subsection{Ash, Macro-, and Micro-Minerals Content}

Here, we also report the ash, macro- and micro-minerals content of whole grain in relation to both genotype and cropping system. It is well known that the 'genotype $\times$ cropping system' interaction 
has a significant effect upon the crop yield and quality performances [39-41]. In the present work, ANOVA outcomes showed statistical significance for the interaction 'cropping system $\times$ genotype', except for $\mathrm{K}$ and $\mathrm{Na}$ (Table 6). The cropping system appeared to be the predominant factor influencing the minerals content, because it reported a higher source of variation than the genotype, excluding $\mathrm{Ca}$ and $\mathrm{K}$ (Table 6). Moreover, the cropping system explained more than $50 \%$ of the total variation for $\mathrm{Mn}(77.6 \%), \mathrm{K}(73.9 \%), \mathrm{Na}(72.9 \%), \mathrm{Fe}(58.7 \%)$, and $\mathrm{Cu}(52.4 \%)$ (Table 6). Thus, the high concentration of mineral elements in the present study might be attributed to the cropping system adopted and reflects the influence of soil supply of nutrients and the different genetic efficiency of nutrients uptake. Nevertheless, because of a poor number of studies, comparison of the mineral composition in CONV and ORG grains with literature data is still difficult. In addition, to our knowledge, all previous investigations concerning the genotypic variation of mineral concentration in relation to the cropping system, except for the work conducted by Ryan et al. [18], have been not carried out on the whole grain. Sometimes literature reports also appeared to be contradictory in relation to the adopted cropping system. For instance, Mäder et al. [16] assessed the lack of significant differences for the content of ash and most minerals for wheat produced in organic and inorganic cropping systems, whereas others found significant differences $[18,19]$.

In particular, Nitika et al. [19] reported that $\mathrm{Cu}$ and $\mathrm{Mn}$ contents were significantly higher in CONV grown wheat varieties as compared with ORG grown ones. In this work similar results were found, since all the considered micro-elements were significantly highest in the CONV cropping system, even if the response was genotype-dependent (Table 7). For example, 'Claudio' and 'Saragolla' had the higher values of $\mathrm{Fe}, \mathrm{Mn}$, and $\mathrm{Zn}$ in the ORG cropping system. On the contrary, the macro-elements, except for $\mathrm{P}$, showed an opposite behavior (Tables 4 and 8). This trend was in agreement with the findings of Ryan et al. [18], which reported that CONV grain had higher $\mathrm{P}$ and lower $\mathrm{Zn}$ and $\mathrm{Cu}$ contents than ORG ones. This discrepancy could be explained taking into account that the experiments were undertaken in different environments. The environmental factor could gain an important role on the mineral elements' concentration, as observed in a collection of Italian durum wheat genotypes [42], and in other crops [43-45].

Highly significant variation existed among genotypes for the concentration of ash and each mineral, except for $\mathrm{Na}$, indicating the potential for genetic improvement of such qualitative traits (Tables 4 and 8). In terms of ash level, 'Ramirez' and 'Tirex' recorded the highest content (2.2\% DM, respectively), while the lowest one was observed in 'Anco Marzio' (1.6\% DM) (Table 4). The coefficient of variation was $3-36 \%$ for the macro-minerals, but only $5-23 \%$ for the micro-minerals (Tables 4,7 and 8 ); perhaps because macro-mineral content has a higher heritability than micro-mineral ones. A similar trend was observed in a previous work on the mineral profile of globe artichoke genotypes [46]. The concentration ranges of the micro-minerals, i.e., $\mathrm{Cu}, \mathrm{Fe}, \mathrm{Mn}$, and $\mathrm{Zn}$ were $1.8-2.1,15.0-27.8,17.5-36.8$, and $11.8-25.2 \mathrm{mg} \mathrm{kg}^{-1}$ of $\mathrm{FW}$, respectively, whereas the ranges for the macro-minerals, i.e., $\mathrm{Ca}, \mathrm{K}, \mathrm{Na}, \mathrm{Mg}$, and $\mathrm{P}$ were $233-425,5200-3148$, 69-76, 1295-1663, and 1680-4071 $\mathrm{mg} \mathrm{kg}^{-1}$ of FW, respectively (Tables 4, 7 and 8). Genotypes with the significant highest and lowest micro-mineral contents were 'Mongibello' and 'Duilio' (2.1 and $1.8 \mathrm{mg} \mathrm{kg}^{-1}$ of FW) for Cu, 'Core', and 'Duilio' (27.8 and $15.0 \mathrm{mg} \mathrm{kg}^{-1}$ of FW) for Fe, 'Ramirez', and 'Duilio' (36.8 and $17.5 \mathrm{mg} \mathrm{kg}^{-1}$ of FW) for Mn, and 'Ramirez', and 'Duilio' (25.2 and $11.8 \mathrm{mg} \mathrm{kg}^{-1}$ of FW) for Zn (Table 7). The wide genetic variability found for Fe and $\mathrm{Zn}$ represents an important result in terms of breeding program, since the modern varieties have limited variation [47]. Therefore, this gene pool could be investigated for future QTL mapping and breeding biofortified wheat [47,48]. In relation to the macro-mineral elements, the significant highest and lowest contents were found in 'Saragolla' and 'Core' (425 and $233 \mathrm{mg} \mathrm{kg}^{-1}$ of FW) for Ca, 'Duilio', and 'Ramirez' (5200 and $3148 \mathrm{mg} \mathrm{kg}^{-1}$ of FW) for K, 'Tirex', and 'Ramirez' (1663 and $1295 \mathrm{mg} \mathrm{kg}^{-1}$ of FW) for Mg, and 'Tirex', and 'Duilio' (4071 and $1511 \mathrm{mg} \mathrm{kg}^{-1}$ of FW) for P (Tables 4 and 8). In general, high mean levels of most of the minerals were found compared to previous studies on whole grain $[12,18]$. Overall our data showed that the $\mathrm{Na} / \mathrm{K}$ ratio was very low $(0.02)$ (Table 4$)$, in agreement with Rodriguez et al. [49]. The $\mathrm{Na} / \mathrm{K}$ ratio is an important health parameter, since high values are associated with an increased risk of elevated blood pressure and cardiovascular disease [50]. 
Table 6. Mean square per each source of variation (percentage of total) resulting from the analysis of variance.

\begin{tabular}{|c|c|c|c|c|c|c|c|c|c|c|c|}
\hline \multirow{2}{*}{ Source of Variation } & \multirow{2}{*}{ Degree of Freedom } & \multicolumn{10}{|c|}{ Mineral Elements } \\
\hline & & $\mathrm{Ca}$ & $\mathbf{K}$ & $\mathrm{Mg}$ & $\mathrm{Na}$ & $\mathbf{P}$ & $\mathrm{Na} / \mathrm{K}$ & $\mathrm{Cu}$ & $\mathrm{Fe}$ & Mn & $\mathrm{Zn}$ \\
\hline Cropping system (CS) & 1 & $0.9^{\mathrm{NS}}$ & $25.4^{* * *}$ & $35.4^{* *}$ & $72.9^{* * *}$ & $33.6^{* * *}$ & $15.7^{\mathrm{NS}+}$ & $52.4^{* * *}$ & $58.7^{* * *}$ & $77.6^{* * *}$ & $39.0 * * *$ \\
\hline Genotype $(G)$ & 8 & $25.2^{* * *}$ & $73.9^{* * *}$ & $20.4^{* * *}$ & $16.1 \mathrm{NS}$ & $36.3^{* * *}$ & $21.6^{\mathrm{NS}}$ & $31.5^{* *}$ & $10.8^{* * *}$ & $10.4^{* * *}$ & $19.3^{* * *}$ \\
\hline $\mathrm{CS} \times \mathrm{G}$ & 8 & $73.9^{* * *}$ & $0.7^{\mathrm{NS}}$ & $44.2^{* * *}$ & 11.0 NS & $30.1^{* * *}$ & $62.6^{\mathrm{NS}}$ & $16.1 *$ & $30.5^{* * *}$ & $12.0^{* *}$ & $41.7^{* * *}$ \\
\hline
\end{tabular}

$* * * * *$, and ${ }^{*}$ indicate significant at $p \leq 0.001, p \leq 0.01$, and $p \leq 0.05$, and ${ }^{\dagger} \mathrm{NS}$, not significant.

Table 7. Micro-minerals content ( $\mathrm{mg} \mathrm{kg}^{-1}$ of fresh weight) as affected by 'cropping system $(\mathrm{CS}) \times$ genotype $(\mathrm{G})$ ' interaction. Different letters (a-e or A, B) within each main factor indicate significance differences (LSD test, $p \leq 0.05)$. All data are expressed as mean \pm standard deviation.

\begin{tabular}{|c|c|c|c|c|c|c|c|c|c|c|c|c|c|c|c|}
\hline \multirow{3}{*}{$\begin{array}{l}\text { Variable } \\
\text { Genotype }\end{array}$} & \multicolumn{4}{|c|}{$\mathrm{Cu}$} & \multicolumn{4}{|c|}{$\mathrm{Fe}$} & \multicolumn{3}{|c|}{ Mn } & \multicolumn{4}{|c|}{$\mathrm{Zn}$} \\
\hline & $\mathrm{ORG}^{+}$ & CONV $\ddagger$ & \multicolumn{2}{|c|}{ Mean } & ORG & CONV & \multicolumn{2}{|c|}{ Mean } & ORG & CONV & Mean & ORG & CONV & \multicolumn{2}{|c|}{ Mean } \\
\hline & & & & & & & & & & & & & & & \\
\hline Anco Marzio & $2.0 \pm 0.1$ & 2.1 & 2.0 & $a b$ & $16.0 \pm 0.3$ & $31.1 \pm 1.0$ & 23.5 & $\mathbf{b}$ & $18.7 \pm 0.5$ & $39.3 \pm 0.4$ & $29.0 \mathrm{~b}$ & $12.3 \pm 0.3$ & $23.3 \pm 0.4$ & 17.8 & bc \\
\hline Claudio & 2.0 & $2.0 \pm 0.1$ & 2.0 & $a b$ & $26.3 \pm 1.5$ & $16.6 \pm 0.4$ & 21.4 & $\mathbf{b}$ & $29.9 \pm 0.6$ & $18.8 \pm 0.5$ & $24.4 \mathrm{c}$ & $25.3 \pm 2.4$ & $12.5 \pm 0.4$ & 18.9 & $\mathbf{b}$ \\
\hline Core & 1.8 & $1.9 \pm 0.2$ & 1.9 & $\mathbf{b}$ & $14.7 \pm 0.2$ & $41.0 \pm 2.6$ & 27.8 & $\mathbf{a}$ & $16.9 \pm 0.2$ & $23.7 \pm 1.0$ & $20.3 \mathrm{~d}$ & $11.6 \pm 0.2$ & $20.2 \pm 2.7$ & 15.9 & c \\
\hline Duilio & $1.8 \pm 0.2$ & 1.9 & 1.8 & $\mathbf{b}$ & $14.4 \pm 0.8$ & $15.7 \pm 0.1$ & 15.0 & c & 16.5 & $18.5 \pm 0.1$ & $17.5 \mathrm{e}$ & $11.4 \pm 1.3$ & $12.3 \pm 0.1$ & 11.8 & d \\
\hline Mongibello & 2.0 & 2.2 & 2.1 & $\mathbf{a}$ & $16.6 \pm 0.5$ & $28.2 \pm 1.4$ & 22.4 & $\mathbf{b}$ & 18.8 & $42.6 \pm 1.8$ & $30.7 \mathrm{~b}$ & $12.9 \pm 0.2$ & 25.2 & 19.1 & $\mathbf{b}$ \\
\hline Ramirez & 2.2 & $2.0 \pm 0.1$ & 2.1 & $\mathbf{a}$ & $30.8 \pm 2.6$ & $24.2 \pm 2.4$ & 27.5 & $\mathbf{a}$ & $28.3 \pm 0.7$ & $45.4 \pm 2.8$ & 36.8 a & $27.2 \pm 0.3$ & $23.2 \pm 0.4$ & 25.2 & $\mathbf{a}$ \\
\hline Saragolla & $1.9 \pm 0.2$ & 2.0 & 1.9 & $\mathbf{b}$ & $26.2 \pm 2.7$ & $16.4 \pm 0.1$ & 21.3 & $\mathbf{b}$ & $23.2 \pm 0.1$ & $19.0 \pm 0.1$ & $21.1 \mathrm{~d}$ & $23.1 \pm 2.7$ & $12.5 \pm 0.1$ & 17.8 & bc \\
\hline Simeto & $1.9 \pm 0.1$ & 2.1 & 2.0 & $a b$ & $15.6 \pm 0.4$ & $28.1 \pm 2.6$ & 21.9 & $\mathbf{b}$ & $17.9 \pm 0.5$ & $40.8 \pm 2.3$ & $29.4 \mathrm{~b}$ & $12.2 \pm 0.3$ & $24.2 \pm 0.2$ & 18.2 & bc \\
\hline Tirex & 2.0 & 2.1 & 2.0 & $a b$ & $16.0 \pm 0.2$ & $28.3 \pm 1.0$ & 22.2 & $\mathbf{b}$ & $18.5 \pm 0.3$ & $41.2 \pm 1.3$ & $29.9 \mathrm{~b}$ & $12.7 \pm 0.2$ & $25.0 \pm 0.1$ & 18.8 & b \\
\hline Mean & 1.9 & $2.0 \quad \mathrm{~A}$ & & & 19.6 & 25.5 & & & 21.0 & 32.2 & & 16.5 & 19.8 & & \\
\hline
\end{tabular}

LSD

interaction

$\mathrm{CS} \times \mathrm{G}$

0.07

4.7

2.9

2.5

${ }^{\dagger}$ ORG: organic cropping system; ${ }^{\ddagger}$ CONV: conventional cropping system. 
Table 8. Macro-minerals content $\left(\mathrm{mg} \mathrm{kg}^{-1}\right.$ fresh weight) as affected by 'cropping system (CS) $\times$ genotype $(\mathrm{G})$ ' interaction. Different letters (a-e or A, B) within each main factor indicate significance differences (LSD test, $p \leq 0.05)$. All data are expressed as mean \pm standard deviation.

\begin{tabular}{|c|c|c|c|c|c|c|c|c|c|c|c|c|c|c|c|c|c|}
\hline \multirow{2}{*}{ Variable } & \multicolumn{6}{|c|}{$\mathrm{Ca}$} & \multicolumn{6}{|c|}{$\mathrm{Mg}$} & \multicolumn{5}{|c|}{$\mathbf{P}$} \\
\hline & \multicolumn{2}{|c|}{$\mathrm{ORG}^{+}$} & \multicolumn{2}{|c|}{ CONV $\ddagger$} & \multicolumn{2}{|c|}{ Mean } & \multicolumn{2}{|c|}{ ORG } & \multicolumn{2}{|c|}{ CONV } & \multicolumn{2}{|c|}{ Mean } & \multicolumn{2}{|c|}{ ORG } & \multicolumn{2}{|c|}{ CONV } & Mean \\
\hline \multicolumn{18}{|l|}{ Genotype } \\
\hline Anco Marzio & \multirow{2}{*}{\multicolumn{2}{|c|}{$\begin{array}{c}345 \pm 12.4 \\
275 \pm 5.8\end{array}$}} & \multicolumn{2}{|c|}{$215 \pm 3.8$} & 280 & c & \multicolumn{2}{|c|}{$1598 \pm 18.0$} & \multicolumn{2}{|c|}{$1411 \pm 21.5$} & 1505 & & \multicolumn{2}{|c|}{$1650 \pm 26.3$} & \multicolumn{2}{|c|}{$2661 \pm 33.1$} & 2156 \\
\hline Claudio & & & \multirow{2}{*}{\multicolumn{2}{|c|}{$\begin{array}{l}4 / 1 \pm 11.0 \\
211+111\end{array}$}} & 373 & b & \multicolumn{2}{|c|}{$1260 \pm 27.7$} & \multicolumn{2}{|c|}{$1578 \pm 28.9$} & 1419 & bc & \multicolumn{2}{|c|}{$1621 \pm 20.0$} & \multicolumn{2}{|c|}{$1739 \pm 18.0$} & 1680 \\
\hline Core & \multicolumn{2}{|c|}{$255 \pm 2.7$} & & & 233 & c & 1626 & 26.5 & 1431 & 14.4 & 1529 & $\mathbf{b}$ & \multirow{2}{*}{\multicolumn{2}{|c|}{$\begin{array}{l}1587 \pm 15.5 \\
1407 \pm 24.4\end{array}$}} & \multirow{2}{*}{\multicolumn{2}{|c|}{$2313 \pm 33.8$}} & $1950 \mathrm{~d}$ \\
\hline Duilio & \multicolumn{2}{|c|}{$250 \pm 16.8$} & \multicolumn{2}{|c|}{$499 \pm 15.5$} & 375 & b & \multicolumn{2}{|c|}{$1518 \pm 27.1$} & \multicolumn{2}{|c|}{$1487 \pm 27.2$} & 1502 & bc & & & & & $1840 \mathrm{~d}$ \\
\hline Mongibello & \multicolumn{2}{|c|}{$521 \pm 3.1$} & $230 \pm$ & & 376 & b & 1511 & 29.4 & 1304 & 26.3 & 1408 & cd & $3384=$ & 25.7 & 1991 & 17.3 & 2687 \\
\hline Ramirez & $307 \pm$ & 12.5 & $211 \pm$ & 10.1 & 259 & c & 1311 & 20.1 & 1279 & 12.4 & 1295 & d & 1101 & 14.2 & 2300 & 16.1 & 1701 \\
\hline Saragolla & $224 \pm$ & 11.8 & $626 \pm$ & 13.4 & 425 & $\mathbf{a}$ & 1229 & 16.0 & 1615 & 14.2 & 1422 & bc & $3762=$ & 38.1 & 2314 & 25.7 & $3038 \mathrm{~b}$ \\
\hline Simeto & $452 \pm$ & 15.6 & $213 \pm$ & 17.0 & 333 & b & 1595 & 19.5 & 1332 & 12.4 & 1464 & bc & $3410=$ & 32.7 & 3283 & 30.1 & 3347 \\
\hline Tirex & $311 \pm$ & 23.6 & $186 \pm$ & 11.1 & 248 & c & 1958 & 17.3 & 1368 & 13.4 & 1663 & $\mathbf{a}$ & 2321 & 22.2 & 5821 & 36.3 & 4071 \\
\hline Mean & 327 & A & 318 & B & & & 1512 & $\mathbf{A}$ & 1423 & B & & & 2213 & B & 2781 & A & \\
\hline $\begin{array}{c}\text { LSD } \\
\text { interaction }\end{array}$ & & & & & & & & & & & & & & & & & \\
\hline $\mathrm{CS} \times \mathrm{G}$ & & & 52 & & & & & & 1 & & & & & & & & \\
\hline
\end{tabular}

\section{Conclusions}

A clear understanding of the relationships between cropping system and product nutritional quality is definitely useful to the community, given that research data on this topic are limited, and very important for designing agricultural management strategies which are environmentally sustainable while able to improve consumer's health parameters in the product. This study provided a better understanding about the effect of cropping system (ORG vs. CONV) on yield and some quality traits of nine whole grain durum wheat genotypes. As expected, a relationship between whole grain quality and cropping system was found. In particular, the results showed that the cropping system affected the yield, rheological traits, and chemical parameters, such as TPC, levels of ash, and some minerals ( $\mathrm{Na}$, $\mathrm{K}$, and $\mathrm{Fe}$ ), much more than the genetic factor. The CONV cropping system appeared to determine better performance than ORG ones in terms of grain yield, protein content, $\mathrm{W}$, and wet gluten and microelements levels $(\mathrm{Cu}, \mathrm{Fe}, \mathrm{Mn}, \mathrm{Zn})$, although with different genotypic response. On the contrary, the level of macro-elements (except for the P), TPC, and AA were highest in the ORG cropping system. This could help to select genotypes with a higher contribution to the daily intake of minerals and bioactive compounds. The present data indicated the possibility to select some durum wheat genotypes ('Duilio' and 'Tirex') with both high TPC and AA levels. Indeed, a positive correlation was found between such traits, suggesting that they may be combined relatively easily in breeding programs. High levels of microelements were observed in 'Ramirez', whereas no significant differences were found in terms of $\mathrm{Na}$ among the genotypes. 'Mongibello' showed both the highest $\mathrm{W}$ and protein content. The present study highlighted that some genotypes such as 'Claudio' and 'Anco Marzio' (only for wet gluten and ash) could be used both in ORG and CONV cropping systems, while 'Mongibello' was more adapted to ORG cropping system in terms of yield, W, protein, and microelements content. Overall, our results would support the efforts of screening and breeding programs for the development and commercial production of durum wheat genotypes with enhanced health and nutritional characteristics, in addition to high crop yield. Nevertheless, it must be borne in mind that the present data originated from samples grown on one site in one year. Therefore, considering that both agronomic performance and quality traits could be affected by environmental conditions and growing season, further investigations are needed in order to provide a complete description of the genotype behavior in relation to the growing area.

Author Contributions: Conceptualization, G.M. and G.M.L.; methodology, G.P., E.M. and S.L.; chemical analysis, G.P., E.M. and S.L.; writing—original draft preparation, G.M., G.M.L., G.P., E.M. and S.L. All authors have read and agree to the published version of the manuscript. 
Funding: This research received no external funding.

Conflicts of Interest: The authors declare no conflict of interest.

\section{References}

1. Venora, G.; Grillo, O.; Saccone, R. Quality assessment of durum wheat storage centres in Sicily: Evaluation of vitreous, starchy and shrunken kernels using an image analysis system. J. Cereal Sci. 2009, 49, 429-440. [CrossRef]

2. Mattiolo, E.; Licciardello, F.; Lombardo, G.M.; Muratore, G.; Anastasi, U. Volatile profiling of durum wheat kernels by HS-SPME/GC-MS. Eur. Food Res. Technol. 2016, 243, 147-155. [CrossRef]

3. Dinelli, G.; Marotta, I.; Di Silvestro, R.; Bosi, S.; Bregola, V.; Accorsi, M.; Di Loreto, A.; Benedettelli, S.; Ghiselli, L. Agronomic, nutritional and nutraceutical aspects of durum wheat (Triticum durum Desf.) genotypes under low input agricultural management. Ital. J. Agron. 2013, 8, 85-93.

4. ISTAT. Available online: http://dati.istat.it/ (accessed on 10 December 2018).

5. Jensen, M.K.; Koh-Banarjee, P.; Hu, F.B.; Franz, M.; Sampson, L.; Grфnbaek, M.; Rimm, E.B. Intakes of whole grains, bran, and germ and the risk of coronary hearth disease in men. Am. J. Clin. Nutr. 2004, 80, 1492-1499. [CrossRef]

6. Slavin, J. Why whole grains are protective: Biological mechanisms. Proc. Nutr. Soc. 2003, 62, 129-134. [CrossRef]

7. Marquardt, L.; Asp, N.G.; Richardson, P. Whole grain health claims in the United States, United Kingdom and Sweden. In Dietary Fibre_Bioactive Carbohydrates in Food and Feed; Kamp, J.W., Asp, N.-G., Miller Jones, J., Schaafsma, G., Eds.; Wageningen Academic Publishers: Wageningen, The Netherlands, 2004; pp. 39-57.

8. Ragaee, A.; Abdel-Aal, E.M.; Noaman, M. Antioxidant activity and nutrient composition of selected cereals for food use. Food Chem. 2005, 98, 32-38. [CrossRef]

9. Adom, K.K.; Sorrells, M.E.; Liu, R.H. Phytochemical profiles and antioxidant activity of wheat varieties. J. Agric. Food Chem. 2003, 51, 7825-7834. [CrossRef]

10. Mc Keown, N.; Meigs, J.B.; Liu, S.; Wilson, P.W.F.; Jacques, P.F. Whole-grain intake is favourably associated with metabolic risk factors for type 2 diabetes and cardiovascular disease in the Framingham Offspring Study. Am. J. Clin. Nutr. 2002, 76, 390-398. [CrossRef]

11. Center for Food Safety and Applied Nutrition. Available online: https://www.fda.gov/food/news-eventscfsan/cfsan-constituent-updates (accessed on 10 December 2018).

12. Hussain, A.; Larsson, H.; Kuktaite, R.; Johansson, E. Mineral composition of organically grown wheat genotypes: Contribution to daily minerals intake. Int. J. Environ. Res. Public Health 2010, 7, 3442-3456. [CrossRef]

13. Zhang, Y.; Song, Q.; Yan, J.; Tang, J.; Zhao, R.; Zhang, Y.; He, Z.; Zou, C.; Ortiz-Monasterio, I. Mineral element concentrations in grains of chinese wheat cultivars. Euphytica 2010, 174, 303-313. [CrossRef]

14. Shewry, P.R.; Hey, S.J. The contribution of wheat to human diet and health. Food Energy Secur. 2015, 4, 178-202. [CrossRef]

15. Gupta, R.B.; Batey, I.L.; MacRitchie, F. Relationships between protein composition and functional properties of wheat flours. Cereal Chem. 1992, 69, 125-131.

16. Mäder, P.; Hahn, D.; Dubois, D.; Gunst, L.; Alföldi, T.; Bergmann, H.; Oehme, M.; Amadò, R.; Schneider, H.; Graf, U.; et al. Wheat quality in organic and conventional farming: Results of a 21 year field experiment. J. Sci. Food Agric. 2007, 87, 1826-1835. [CrossRef]

17. Dangour, A.D.; Dodhia, S.K.; Hayter, A.; Allen, E.; Lock, K.; Uary, R. Nutritional quality of organic foods: A systemic review. Am. J. Clin. Nutr. 2009, 10, 680-685. [CrossRef]

18. Ryan, M.; Derrick, J.; Dann, P. Grain mineral concentrations and yield of wheat grown under organic and conventional management. J. Sci. Food Agri. 2004, 84, 207-216. [CrossRef]

19. Nitika, D.P.; Khetarpaul, N. Physico-chemical characteristics, nutrient composition and consumer acceptability of wheat varieties grown under organic and inorganic farming conditions. Int. J. Food Sci. Nutr. 2008, 59, 224-245. [CrossRef]

20. Quaranta, F.; Belocchi, A.; Fornara, M.; Ripa, C.; D’Egidio, M.G. Le Varietà di Frumento duro in Italia. Risultati della rete Nazionale di Sperimentazione 1999-2012; Consiglio per la Ricerca e la Sperimentazione in Agricoltura: Rome, Italy, 2013; ISBN 978-88-97081-31-9. 
21. Zadoks, J.C.; Chang, T.T.; Konzak, C.F. A Decimal code for the growth stages of cereals. Weed Res. 1974, 14, 415-421. [CrossRef]

22. Menga, V.; Fares, C.; Troccoli, A.; Cattivelli, L.; Baiano, A. Effects of genotype, location and baking on the phenolic content and some antioxidant properties of cereal species. Int. J. Food Sci. Technol. 2010, 45, 7-16. [CrossRef]

23. Brand-Williams, W.; Cuvelier, M.E.; Berset, C. Use of a free radical method to evaluate antioxidant activity. Food Sci. Tech. 1995, 22, 25-30. [CrossRef]

24. Quaranta, F.; Amoriello, T.; Aureli, G.; Belocchi, A.; D’Egidio, M.G.; Fornara, M.; Melloni, S.; Desiderio, E. Grain yield, quality and deoxynivalenol (DON) contamination of durum wheat (Triticum Durum Desf.): Results of national networks in organic and conventional cropping systems. Ital. J. Agron. 2010, 4, 353-366. [CrossRef]

25. Vaccari, F.P.; Ranieri, R.; Matese, A.; Miglietta, F. Enhanced temperature during grain filling reduces protein concentration of durum wheat. Ital. J. Agron. 2007, 4, 393-400. [CrossRef]

26. Galterio, G.; Biancolatte, E.; Autran, J.C. Proteins deposition in developing durum wheat. Implications in technology quality. In Proceedings of the 3rd International Workshop on Gluten Proteins, Budapest, Hungary, 9-12 May 1987; Lasztity, R., Bekes, F., Eds.; World Scientific: Singapore, 1987; pp. 284-298.

27. Kovacs, M.I.P.; Poste, L.M.; Butler, G.; Woods, S.M.; Leisle, D.; Noll, J.S.; Dahlke, G. Durum wheat quality: Comparison of chemical and rheological screening tests with sensory analysis. J. Cereal Sci. 1997, 25, 65-75. [CrossRef]

28. Autran, J.C.; Hamer, R.J.; Plitjer, J.J.; Pogna, N.E. Exploring and improving the industrial uses of wheat. Cereal Foods World 1997, 42, 221-226.

29. Simic, G.; Horvat, D.; Jurkovic, Z.; Drezner, G.; Novoselovic, D.; Dvojkovic, K. The genotype effect on the ratio of wet gluten content to total wheat grain protein. J. Cent. Eur. Agric. 2006, 7, 13-18.

30. Indrani, D.; Manohar, R.S.; Rajiv, J.; Venkateswara Rao, G. Alveograph as a tool to assess the quality characteristics of wheat flour for parotta making. J. Food Eng. 2007, 78, 1202-1206. [CrossRef]

31. Zuchowski, J.; Jonczyk, K.; Pecio, L.; Oleszek, W. Phenolic acid concentrations in organically and conventionally cultivated spring and winter wheat. J. Sci. Food Agric. 2011, 91, 1089-1095. [CrossRef]

32. Hallmann, E. The influence of organic and conventional cropping systems on the nutritional value and content of bioactive compounds in selected tomato types. J. Sci. Food Agric. 2012, 92, 2840-2848. [CrossRef]

33. Lombardo, S.; Pandino, G.; Mauromicale, G. The effect on tuber quality of an organic versus a conventional cropping system in the early crop potato. J. Food Compos. Anal. 2017, 62, 189-196. [CrossRef]

34. Zielinski, H.; Kozlowska, H. Antioxidant activity and total phenolics in selected cereal grains and their different morphological fractions. J. Agric. Food Chem. 2000, 48, 2008-2016. [CrossRef]

35. Yu, L.; Haley, S.; Perret, J.; Harris, M.; Wilson, J.; Qian, M. Free radical scavenging properties of wheat extracts. J. Agric. Food Chem. 2002, 50, 1619-1624. [CrossRef]

36. Martini, D.; Taddei, F.; Ciccoritti, R.; Pasquini, M.; Nicoletti, I.; Corradini, D.; D’Egidio, M.G. Variation of total antioxidant activity and of phenolic acid, total phenolics and yellow coloured pigments in durum wheat (Triticum turgidum L. var. durum) as a function of genotype, crop year and growing area. J. Cereal Sci. 2015, 65, 175-185. [CrossRef]

37. Stracke, B.A.; Eitel, J.; Watzl, B.; Mader, P.; Rufer, C.E. Influence of the production method on phytochemical concentrations in whole wheat (Triticum aestivum L.): A comparative study. J. Agr. Food Chem. 2009, 57, 10116-10121. [CrossRef] [PubMed]

38. Bellato, S.; Ciccoritti, R.; Del Frate, V.; Sgrulletta, D.; Carbone, K. Influence of genotype and environment on the content of 5-n alkylresorcinols, total phenols and on the antiradical activity of whole durum wheat grains. J. Cereal Sci. 2013, 57, 162-169. [CrossRef]

39. Murphy, K.M.; Campbell, K.G.; Lyon, S.R.; Jones, S.S. Evidence of varietal adaptation to organic farming systems. Field Crop. Res. 2007, 102, 172-177. [CrossRef]

40. Lombardo, S.; Lo Monaco, A.; Pandino, G.; Parisi, B.; Mauromicale, G. The phenology, yield and tuber composition of 'early' crop potatoes: A comparison between organic and conventional cropping systems. Renew. Agric. Food Syst. 2013, 28, 50-58. [CrossRef]

41. Lombardo, S.; Pandino, G.; Mauromicale, G. Minerals profile of two globe artichoke genotypes as affected by NPK fertilizer regimes. Food Res. Int. 2017, 100, 95-99. [CrossRef] 
42. Ficco, D.B.M.; Riefolo, C.; Nicastro, G.; De Simone, V.; Di Gesù, A.M.; Beleggia, R.; Platani, C.; Cattivelli, L.; De Vita, P. Phytate and mineral elements concentration in a collection of Italian durum wheat genotypes. Field Crop Res. 2009, 111, 235-242. [CrossRef]

43. Scherz, H.; Kirchhoff, E. Trace elements in foods: Zinc contents of raw foods-A comparison of data originating from different geographical regions of the world. J. Food Compos. Anal. 2006, 19, 420-433. [CrossRef]

44. Pandino, G.; Lombardo, S.; Mauromicale, G. Mineral profile in globe artichoke as affected by genotype, head part and environment. J. Sci. Food Agric. 2011, 91, 302-308. [CrossRef]

45. Lombardo, S.; Pandino, G.; Mauromicale, G. The influence of growing environment on the antioxidant and mineral content of "early" crop potato. J. Food Compos. Anal. 2013, 32, 28-35. [CrossRef]

46. Pandino, G.; Lombardo, S.; Mauromicale, G. Chemical and morphological characteristics of new clones and commercial varieties of globe artichoke (Cynara cardunculus var. scolymus). Plant Foods Hum. Nutr. 2011, 66, 291-297. [CrossRef] [PubMed]

47. Liu, J.; Wu, B.; Singh, R.P.; Velu, G. QTL mapping for mineral nutrient concentrations and agronomic-related traits in a hexaploid wheat mapping population. J. Cereal Sci. 2019, 88, 57-64. [CrossRef]

48. Velu, G.; Crespo Herrera, L.; Guzman, C.; Huerta, J.; Payne, T.; Singh, R.P. Assessing genetic diversity to breed competitive biofortified wheat with enhanced grain Zn and Fe concentrations. Front. Plant Sci. 2019, 9, 1971. [CrossRef] [PubMed]

49. Rodríguez, L.H.; Morales, D.A.; Rodríguez, E.; Romero, C.D. Minerals and trace elements in a collection of wheat landraces from the Canary Islands. J. Food Compos. Anal. 2011, 24, 1081-1090. [CrossRef]

50. Krummel, R.D. Nutrición en la hipertension. In Nutrición y dietoterapia de Krause; McGraw Hill: Mexico City, Mexico, 2001; Volume X, p. 1274.

(C) 2020 by the authors. Licensee MDPI, Basel, Switzerland. This article is an open access article distributed under the terms and conditions of the Creative Commons Attribution (CC BY) license (http://creativecommons.org/licenses/by/4.0/). 